Valóságos könyvtár - könyvtári valóság. Könyvtár- és információtudományi tanulmányok 2016. Szerk. Kiszl Péter, Boda Gáborné Köntös Nelli.

Budapest, ELTE BTK Könyvtár- és Információtudományi Intézet. 2017. 15-20.

\title{
A KÖNYVTÁRAKTÓL AZ INTERNETIG?
}

\section{FRANK TIBOR}

ELTE BTK Angol-Amerikai Intézet Amerikanisztika Tanszék, egyetemi tanár

\begin{abstract}
ABSZTRAKT
Az egyetemi oktatás során mind gyakrabban ütközöm abba az akadályba, hogy diákjaim - még a legkiválóbbak is - ódzkodnak a könyvtárak használatától, és egyre kizárólagosabban az internettől, az adatbázisoktól, a virtuálisan s nem a kézbe foghatóan létező forrásoktól, adatoktól remélik feladataik megoldását. Minden félévben megdöbbent, hogy a nagy múltú egyetemünkön tanuló hallgatók milyen kevéssé ismerik akár a legnagyobb budapesti könyvtárakat is, s hogy milyen sikere van azoknak a kurzusaimnak, amelyek - legalább a tanulmányi idô felében - könyvtárlátogatásokat is magukba foglalnak. Ilyen alkalmakkor szinte mindenkit meglep, hogy az Országos Széchényi Könyvtár, az Eötvös Loránd Tudományegyetem Egyetemi Könyvtára és hálózati könyvtárai, a Fôvárosi Szabó Ervin Könyvtár központi gyújteménye, az MTA Akadémiai Könyvtára és kutatóintézeti gyüjteményei, az Országgyúlési Könyvtár, illetve az Országos Idegennyelvű Könyvtár nagyszabású budapesti gyüjtemény-együttese a maga közel 20 milliós (s így akár a washingtoni Library of Congress anyagához is közel jutó) könyvtári dokumentumával micsoda gazdagságát kínálja az elsődleges és másodlagos forrásoknak, a szakirodalomnak, a különgyúijteményeknek. Mégis, a diákok többsége ritkán vállalkozik a sokszor gyalogosan is megtehető útra, és szívesebben marad számítógépe mellett, ahonnan valamennyi kérdésére választ vár - és sokszor hiába. Mi ennek a távolságtartásnak, illetve vonzalomnak a pontosabb oka? Kényelemszeretet vagy ismerethiány? Rossz könyvtári propaganda, hiányos vagy elmaradozó könyvtár- (és könyv-) kezelési oktatás vagy az adatbázisok világának nálunk viszonylag hirtelen történő kinyilása? A számítógépek vonzó variabilitása, adatkapcsolati lehetőségei - esetleg könnyü: 'cut and paste' - adatkezelési technikái, szemben a régimódibb (és Magyarországon sokszor még ma is a kompjuterizálás gyermekkorát idéző) könyvtárhasználati lehetőségekkel? Ismerethiány, lustaság vagy a gépesített ismeretközlés és -továbbítás forradalmian új lehetőségei iránti szerelem? Az ismeretszerzés legtöbbször (de nem csak) jó értelmű „amerikanizálódásának” gyorsütemű térhódítása? Mit tehet a könyvtár és tudománya az egyensúly helyreállitásának, a hagyományos gyűjtemények szerepének legalább részleges visszanyerése érdekében? Mit tesznek az amerikai (és sokszor az amerikanizált nyugat-európai) könyvtárak a könyvtárhasználat megkönnyítése, a valódi könyv és a valóságos könyvtár megszerettetése, lehetőségeik jobb és korszerübb kihasználása érdekében?
\end{abstract}

I.

Az általános iskola elvégzése után, s aztán gimnáziumi nyaraimon nyári állást kerestem. Először egy kertészetben kaptam munkát, de ez nem váltotta be reményeimet és más, vonzóbb lehetőséggel próbálkoztam. Az Egyetemünkön dolgozó Édesanyám segítségével az Egyetemi Könyvtárba kerültem, ahol - akkor Mátrai László kissé bör- 
tönőrszerú igazgatása alatt - kiváló szakemberek dolgoztak, akiktől rengeteg tanulhattam. A könyvtár akkor menedéket nyújtott a rendszer ellenfeleinek, korábban többek között Bibó István és Szalai Sándor is ott dolgozott egy ideig. Az én időmben (1962-tôl töltöttem ott több nyaramat) a kiválóan felkészült történész Tóth András volt a Szerzeményi Osztály vezetője, a munkatársak között volt Keresztényi József olimpiatörténész, Szalatnai Rezső, a Felvidékrôl leszármazó történész-író, Vértesy Miklós, Pajkossy Györgyné és Déri Miklósné könyvtárszakértők. Az igazgató könyvtáros-szaktudós helyettese Domanovszky Ákos volt.

Én a kitűnő, elsősorban franciás műveltségű Szabó-Froreich Antallal a kardex nevú folyóirat-nyilvántartás naprakész ellenőrzésében kaptam feladatot - máig emlékszem, ahogyan minden külföldi folyóirat címét az adott nyelv kiejtési szabályai-szokásai szerint mondta ki - minden esetben kifogástalanul. Akkor még sok százával jártak a szaklapok a budapesti Egyetemi Könyvtárba, amely tekintélyes tudományos központ volt, amellett, hogy sokáig egyetlen, ténylegesen könyvtárnak épült hazai intézményünk. Azokon a nyarakon megismertem a könyvtár erényeit és fogyatékosságait, az utóbbiak közül elsősorban azt, hogy a tudományos olvasótermen kívül, ahol referencia-kötetek sorakoztak a polcokon, lényegében minden könyv és folyóirat zárt raktárrendszerben kapott helyet, ahol a kötetek a könyvtárba való beérkezési sorrend szerint, tehát mindennemú tartalmi összefüggés nélkül kerültek a polcokra, és a beérkezésükkor, a Szerzeményi Osztályon bepecsételt nyilvántartási számuk szerint sorakoztak. Innen csak a raktárosok hozhatták ki az olvasnivalót, az access to information útját a magyar rendszer akkor a legszigorúbban ellenőrizte és mereven korlátozta. Még élt a szabály, hogy 5000 kötetenként egy-egy könyvtárosi hely illette meg a gyüjteményt, és a könyvtárosok nagyobb része nagy műveltségű szakember volt (az Országos Széchényi Könyvtár Nemzeti Múzeumbeli tájékoztatójában például Kemény G. Gábor és Fried István ült), ám a szépen gyarapodó, hatalmas Egyetemi Könyvtárat Mátrai akadémikus vigyázó szemei felügyelték. Ő ugyanis - akkor még meglévő szokás szerint - az épületben lakott is, s ablakából a fáma szerint távcsövön figyelte munkatársainak a szemközti Csemege áruházban töltött tízórai szünetének betartását. Nyáron kiült a Kárpátia étterem bukszusai mögé/alá (igen kistermetű ember volt), s onnan tartotta a percekre, ideiglenesen távozó munkatársakat megfigyelés alatt. Védte is, ellenőrizte is ôket. A munkatársaknak pontosan 8:00 óráig kellett megérkezniük, amit minden reggel - az időpont megjelölésével - aláirásukkal kellett igazolni a ruhatárként is funkcionáló portán. Pontosan 8 órakor az aláírókönyvet felvitték az igazgatóhoz, aki a későn jövőket így név szerint meg tudta feddeni, s ezt olykor meg is tette. A Könyvtár viszont - Mátrai zseniális ötlete nyomán - akkor is, az ateizmus korában is folytatni tudta eredeti teológiai gyújtését, ezt az agnosztikus gondolkodás, a bibliakritika, a vallástörténet címkéi alá bújtatva el, kiegészítve a középkori történelem, illetve a Mátrait személy szerint érdeklő filozófia és pszichológia iránti érdeklődéssel. A korszak kétségtelen vívmánya volt az 1952-ben elfogadott és a könyvtárügy fejlesztéséről szóló 2.042-13/1952 (V. 14.) M.T. számú határozat, amely gyűjtőköröket állapított meg és a könyvtárak szerzeményezési munkáját ezek szerint határozta meg. 
Az Egyetemi Könyvtár nagyolvasóterme a vizsgaidőszakban zsúfolásig megtelt diákokkal, a kölcsönzőben sorban álltak a Nyugat vagy a múlt ablakain kikémlelni vágyó olvasók, a tudományos olvasóban az Egyetem tanárai dolgoztak nap mint nap, Szathmári István nyelvész-professzorra emlékezem ott mindenki előtt. A könyvtári szakszerűség, a tudomány, a politikai elnyomás és a félelem esztendeit éltük, de nekem az Egyetemi Könyvtár szemnyitogató, pályaalapozó, örök emlékezetű hely maradt gyermekkori emlékeimben. Hálásan emlékezem vissza egykori könyvtári munkatársaimra, az akkori könyvtárosi gárda élvonalára.

Az Országos Széchényi Könyvtárnak ebben az időszakban még 16 kötelespéldány járt a nyomdáktól, s erre élénk nemzetközi csere épült - miközben a politikailag veszélyesnek minősített dokumentumokat zárt anyagként őrizte a nemzeti könyvtár. Ezt a részleget példamutató módon, még a rendszerváltás előtt Juhász Gyula akadémikus, az OSZK akkori fóigazgatója szüntette meg és az anyagot a könyvtár rendes állományába helyezték el. De nem csak Magyarországon volt ez a helyzet: még sok évvel később is, a hidegháború vége előtt ugyanezt tapasztaltam mind a Stanford University mellett működő Hoover Institution-ben és a washingtoni National Archives-ben, mind pedig a nagy moszkvai levéltárakban (IML, CGAOR), ahol még 1976-77-ben kutattam.

II.

Külföldi könyvtári tapasztalataim sajnos azt tudatosították bennem, hogy a magyar könyvtárügy jelentősen le van maradva a nemzetközi színvonaltól. Mi a különbség például az amerikai és a magyar könyvtárak között?

Több éven át végzett Fulbright vendégprofesszori munkám (s azt követő amerikai vendégtanári meghívásaim) mellett 1988-tól kezdve számos nagyobb és kisebb könyvtárban, levéltárban dolgoztam, szerte az Egyesült Államokban. Legalaposabban a University of California különféle campusain működő gyüjteményeket ismertem meg, így a UC Santa Barbara, a UC Davidson, a UCLA, majd a University of Nevada-Reno egyetemi könyvtárában, a Columbia University Butler Library-ben dolgoztam, visszatérően. Összesen 45 amerikai köz- és magángyújteményben folytattam könyv- és levéltári kutatómunkát, s ennek alapján azt kellett látnom, hogy az Egyesült Államok nemcsak a gyújtemények megközelítése, feldolgozottsága és technikai felszerelése, hanem általános érvénnyel az információhoz való hozzájutás szabadsága tekintetében is sok-sok mérfölddel előttünk járt és jár még ma is - ha időközben sok vonatkozásban nálunk is megkezdődött a hátrány ledolgozása.

Az access of information, az információhoz történő hozzáférés, hozzájutás szinte egyenesen következik a liberális amerikai szabadságeszmények nagyfokú tiszteletben tartásából, rokonságban van a gondolat-, a szólás-, a vallás- és az akaratszabadság immár majd két és fél évszázad amerikai eszméiből - a francia és a brit felvilágosodás szinte közvetlen hatása nyomán. Ennek technikai megvalósulása a nagy amerikai egyetemek könyvtárainak szinte non-stop, „7/24” nyitva tartása, és különösen a nagyszerűen kifejlesztett, szabadpolcos hozzáférési rendszer, valamint a Library of Congress által min- 
den egyes amerikai könyvnek kinyomtatása előtt közvetlenül juttatott jelzet, melyet az Egyesült Államokban kiadott könyvek mindegyike a belső címlap hátoldalán közöl. A könyvtárak e jelzetek alapján, tematikusan csoportosítják könyvanyagukat, s az így kialakított könyvtárszerkezetben diák és tanára egyaránt könnyen és gyorsan eligazodik. Már-már azt mondtam volna, hogy szinte túl könnyen, hiszen így elmarad az a fajta kutató-kereső munka, amelyen az én nemzedékem még felnőtt és iskolázódott. De a diákok és tanáraik energiái így a szinte „tálcán”, a Library of Congress elsőrangúan képzett könyvtárosai által több lépcsőben előkészített könyvanyag érdemi feldolgozására válnak fordíthatókká, az idő legnagyobb része a szabadpolcokon sorakozó, tematikus szakmai könyvgyűjtések tényleges tanulmányozásával telhet. Tanár és diák munkáját tovább segítik az egész Egyesült Államokban kötelezően használt, szigorú filológiai előírások és módszerek, melyeket a nagyfokú formai egységesítés igénye hívott életre: elsősorban a Modern Language Association (MLA), az American Psychological Association (APA), illetve a University of Chicago által felügyelt, minden elképzelhető részletre kiterjedő Chicago Manual of Style rendszereire gondolok, amelyek javarésze ma már nem csupán nyomtatott, hanem internetes formában is elérhető. Forrásanyag és módszertani előírás tehát minden egyetemi polgárnak automatikusan rendelkezésére áll.

A kutatót a nagyobb egyetemi könyvtárak és a levéltárak féltve őrzött (külön)gyűjteményei is hívogatják, mint a UC Santa Barbara Donald C. Davidson Libraryben felépített Charles Darwin (és evolúciós) gyüjtemény a maga 3400 ritka kötetével, ugyanott az egykori jugoszláv jogtudós és politikus Fedor Nikić 15000 kötetes Balkán-gyűjteménye, a német filozófus Hannah Arendt ugyancsak eredeti könyvtára a New York állambeli Bard College tulajdonában és sok hasonló kollekció. Sok helyen őriznek magyar vonatkozású (külön)gyüjteményeket is. A könyvtárakat egyébként már rutinszerűen közvetlenül is összekötik az egyetemek e-roomjaival, ezekkel az elektronikusan a lehető legkorszerűebben felszerelt tantermekkel, így könyvtár és oktatás a hagyományokhoz képest még egy fontos szálon összekapcsolódik. Egy-egy új kurzus meghirdetésekor, megindításakor az egyetemi oktató nemcsak a könyvtárnak, hanem a campus könyvesboltjának is leadja az általa előírt tankönyvek, forrásmunkák adatait, így azok a félév kezdete előtt már kölcsönözhetők, illetve megvásárolhatók (olcsón is, ha a diák használt példányokkal is megelégszik). A tanárok a kiadóktól a felhasználandó könyvekből ingyenes tanári példányokat kapnak. A levéltárak a leginkább keresett kéziratokat mikrofilmre veszik, ennek egy-egy példányát elküldik a nagy amerikai könyvtári központoknak az Egyesült Államokon kívül is, Berlintől Hajdarábáig (Hyderabad). Az amerikai tudományosság világsikerének, a mára már több százas nagyságrendú Nobel-díjas amerikai diadalának egyik nagy titka az access, a könyvtári hozzájutás gyorsasága, kényelme, precizitása, megbízhatósága.

A titok másik nyitja, ma már nyugodtan hozzátehetjük, az adatbázisok létrehozásának és gazdagításának robbanásszerű menete, ami nálunk is elkezdődött és a hazai egyetemek és főiskolák nemzetközi besorolásának egyik záloga. Talán nem nagy túlzás, hogy a folyóiratok egyre nagyobb számának on-line elérhetősége, az adatbázisok, így elsősorban az EBSCO „család” forradalmasította a tanítás és a tanulás gyakorlatát és 
kapcsolatát a tudományos élettel. S még valami: a könyv- és levéltári anyag, s az ezt feltáró katalógusok, inventáriumok, mutatókönyvek rohamosan folyó (különösen amerikai, de ezen át bennünket is érintő) digitalizálása révén a kutatás már-már „otthonról”, azaz a könyvtáron kívülről is sokféle helyen végezhető, a még nem digitalizált anyagokat számos külföldi könyvtárban a legnagyobb precizitással és biztonsággal 24 órán belül előkészíttethetjük (így már többek között Bécsben is). A digitalizálás, a szabadpolcos rendszerek kiépítése, az adatbázisokra történő rendszeres és jól átgondolt, a könyvtárak között összehangolt előfizetés nélkül a hazai felsőoktatás és kutatás újabb lépéshátrányba kerülhet, kerül is a nemzetközi tudásipar és -forgalom térképén.

\section{III.}

Végül a magyar könyvtárügy előtt álló feladatokról néhány rövid, tézisszerű jelzés:

(1) A könyvtárak szerepének átalakításával talán elkerülhetővé tehetjük az ott összegyưlt, irdatlan tudásanyag muzealizálódását, megakadályozhatjuk devalválódását, funkcióvesztését.

(2) Meg kell akadályoznunk a könyvtári anyag felelőtlen selejtezését, biztosítanunk kell ennek könyvtár-szakmai és szaktudományos kontrollját (ld. az Országgyűlési Könyvtár nemzetközi parlamenti anyagának nem régi, szinte tragikus esetét).

(3) A Fővárosi Szabó Ervin Könyvtár és a Szegedi Egyetem Klebelsberg Kuno Könyvtárának mintájára hozzá kell látnunk valamennyi nagy könyvtárunk modernizálásához, illetve ahol ez a munka elkezdődött, a munkálatok meggyorsításához.

(4) Minden energiával folytatni kell a magyarországi könyv-, folyóirat- és iratanyag digitalizálását, s ezt központi kormányprogrammá kell emelni. Bizarr fejlemény, hogy a magyar anyag digitalizálásában a minnesotai könyvtár messze előttünk jár, s az Egyesült Államok nagy közkönyvtárai ('́gy többek között a Library of Congress, a New York Public Library, a Columbia University Butler Library) néhány éven belül már teljes gyüjteményük scannelését ígérik.

(5) A könyvtárat az eddigieknél hatékonyabban tanulási és művelődési központtá kell tennünk, ehhez proaktív könyvtárosi attitűd és - már a képzésben is - az informatika eredményeinek magas szintű felhasználása szükséges.

(6) Radikálisan fel kell emelni a nemzetközi adatbázisok előfizetésére szánt éves öszszegeket.

(7) Az Egyetemet fel kell szerelni minden diák rendelkeezésére álló komputer-termekkel, benne elegendő számú számítógéppel, nyomtatóval, xerox géppel és scannerrel.

(8) A nagy előadótermeket elektromos vezérlőpulttal kell felszerelni, amelyekrôl az oktatók saját vizuális segédeszközeiket, de az internet által nyújtott egyre gazdagodó kép-, film- és hanganyagot, valamint minden más szemléltető eszközt kezelni tudnak.

(9) Az egyetemi oktatás során gondoskodni kell integrált, korszerű könyvtárhasználati módszertani képzésrôl a szakmai órákon is (források kezelése, bibliográfia készítés, jegyzetelés, internet használat, adatbázisok felhasználása). 


\section{FRANK TIBOR}

A könyvtáraktól az internetig? Nagy utat jártak be hazai könyvtáraink a II. világháború óta, de még hosszabb út áll előttük. Az ELTE Könyvtár- és Információtudományi Intézetének konferencia sorozata ennek az útnak fontos állomása, s reményeink szerint előre lendítő motorja.

\section{Irodalom}

Az Egyetemi Könyvtár Évkönyvei: Annales Bibiliothecae Universitatis de Rolando Eötvös Nominitae. 1-16. köt. Budapest, Tankönyvkiadó, 1962-.

KOVÁCS Máté (szerk.): A könyv és könyvtár a magyar társadalom életében 1849-től 1945-ig. Budapest, Gondolat, 1970. 722, [1] p.

MÁTRAI László: A kultúra történetisége: válogatott tanulmányok és cikkek. Budapest, Gondolat, $1977.417 \mathrm{p}$.

POGÁNYNÉ RÓZSA Gabriella: Két könyvtári törvénytervezet, 1947-1950. = Könyv, Könyvtár, Könyvtáros, 17. évf. 2. sz. 2008. 44-51. p.

SÁRDY Péter: Áttekintés a magyar könyvtárügy fejlődéséről és helyzetéről. = Könyvtári Figyelő, 27. évf. különszám. 1981. 13-18. p.

SKALICZKI Judit: Az Európai Unió és a hazai könyvtárügy. = Könyvtári Levelező/lap, 10. évf. 6-7. sz. 1998. 1-3. p.

VARGA Katalin - MÉSZÁROSNÉ SZENTIRÁNYI Zita (szerk.): Összehasonlít(hat)ó könyvtárügy: tanulmánykötet a PTE FEEK 10 éves Könyvtár- és Információtudományi Intézete oktatóinak és hallgatóinak munkáiból. Pécs, PTE FEEK, 2014. 366 p.

Internetes források

American Library Directory. Forrás: http:/ / www.americanlibrarydirectory.com [2016. április 30.]

The Atlantic. Forrás: http://www.theatlantic.com/national/archive/2016/02/old-libraries-be[-] coming-new/460494 [2016. április 30.]

Digital Public Library of America. Forrás: https://dp.la [2016. április 30.]

I Love Libraries. Forrás: http:/ /www.ilovelibraries.org [2016. április 30.]

Mental Floss. Forrás: http://mentalfloss.com/article/30701/10-amazing-north-american-libraries [2016. április 30.]

USA.gov/Libraries. Forrás: https://www.usa.gov/libraries [2016. április 30.]

Frank Tibor történész, az ELTE BTK Amerikanisztika Tanszékének egyetem tanára, az Angol-Amerikai Intézet korábbi igazgatója (1994-2001, 2006-2014), 2000-től az Amerikanisztika Doktori Program vezetője. Az MTA levelező tagja, a Royal Historical Society (London) tagja, a Századok c. folyóirat főszerkesztője. 